\title{
Comprehensive wilderness protection in British Columbia: An economic impact assessment
}

\author{
by Michael M'Gonigle, Thomas Gunton, Chris Fletcher, Murdoch McAllister \\ and Doug MacKnight ${ }^{1}$
}

This study develops an economic model for assessing the impacts of a comprehensive wilderness proposal on the British Columbia forest industry. The results indicate that, overall, the impacts are relatively small, involving a $3.5 \%$ reduction in the provincial allowable annual cut, with regional impacts ranging from $1.9 \%$ to $5.2 \%$. Some ways to offset these impacts are discussed, since the ability to offset employment loss significantly influences the feasibility of wilderness designations. The study highlights the feasibility of developing quantitative models for assessing the economic impacts of land use options. Extending the model developed in this paper by integrating growth and yield models with a geographical information system and an input-output model would facilitate quick and flexible assessments of alternative land use strategies. Development of such a framework is essential for resolving forestry conflicts.
Cette étude élabore un modèle économique d'évaluation des impacts d'une politique globale pour les grands espaces sur l'industrie forestière de Colombie-Britannique. Les résultats indiquent, tout compte fait, que les impacts sont relativement minimes, entraînant une réduction de $3.5 \%$ de la coupe annuelle permise pour la province, les variations régionales étant de $1.9 \%$ à $5.2 \%$. Des possibilités de déférer ces impacts sont abordées, puisque la capacité de réduire les pertes d'emploi influence significativement la faisabilité de la création de grands espaces. L'étude souligne la possibilité de développer des modèles quantitatifs d'évaluation des impacts économiques selon divers options d'utilisation des terres. Le développement du modèle élaboré dans cette étude par l'intégration des modèles de croissance et de rendement ainsi qu'un système d'information géographique et un modèle d'intrants-extrants permettrait d'évaluer facilement les stratégies alternatives d'utilisation des terres. Le développement d'un tel cadre de travail est essentiel pour résoudre les conflits forestiers
A leading issue in forest policy is the allocation of land between timber and non-timber uses. This issue is particularly intense in British Columbia where environmental groups recently published a map setting out 103 areas in the province they felt warranted protection as preserved wilderness areas (Valhalla Society 1988). This proposal predictably struck a responsive chord with many environmental activists in the province, activists who maintained that negative economic impacts would be minimal. In contrast, the Council of Forest Industries of British Columbia expressed serious concerns that the potential impacts on the forest industry would be extensive (Sasges 1988).

The resolution of land use conflicts requires quantitative assessment of the tradeoffs involved. Despite the significance of the issue, the B.C. government has not undertaken such an analysis and has not developed a comprehensive analytical framework for assessing land use tradeoffs. To provide a more rigorous understanding of these impacts and options, the School of Resource and Environmental Management (NRM) at Simon Fraser University convened a research group to develop a quantitative framework for assessing the province wide economic impacts on the forest industry of land use withdrawals. The framework is applied to a case study of the Valhalla wilderness proposal (NRM 1990) ${ }^{2}$. This is done without considering the benefits and costs which might accrue to other industrial sectors, notably tourism, because such benefits, while important from a broader social and political perspective, will not ameliorate the problems confronting forestry. Further, potential effects on ranching,

\footnotetext{
${ }^{1}$ The authors are associated with the School of Resource and Environmental Management at Simon Fraser University, Burnaby, BC V5A 1S6. The present article is based upon a year-long research project released in 1990. This report is available from the department at a charge of $\$ 15$, plus $\$ 2$ postage.
}

mining, trapping, and other interests were beyond the scope of the study. The purpose of this article is to summarize the results of this research project.

\section{Background: Interests and Values in Conflict}

For many years, battles have raged in British Columbia between the forest industry and environmentalists over the future of individual wilderness areas. Some become highprofile controversies such as that over South Moresby in the Queen Charlotte Islands. Others remain at a local level. These controversies, however, signify more than competition for turf. They involve differences in values and beliefs as to how forests are useful, how they should be managed, and by whom (M'Gonigle 1989). As a result, they pose a challenge to the process by which forest lands are allocated and managed. These planning conflicts extend well beyond the $\mathrm{BC}$ border. This is most dramatically evident in the recent controversy surrounding the proposed new pulp mill developments in northern Alberta and Manitoba, as well as conflicts such as that over the Temagami area of Ontario (Nikiforuk and Struzik 1989, Hall 1990).

In British Columbia, controversy involves two of the province's most important economic sectors. The forest products industry is BC's largest revenue-earning sector with product sales of $\$ 12.7$ billion in 1989 (Council of Forest Industries 1991). Meanwhile, tourism is BC's second largest industry, earning revenues of $\$ 5.0$ billion and generating

\footnotetext{
${ }^{2}$ The research group was composed of Chris Fletcher, Paul Higgins, Mayayuki Kusama, Murdoch McAllister, Douglas MacKnight. Brad Mason. Catherine Milne (co-editor), John Saremba, David Sims (co-editor), Graham Suther, Daryl Tremain, and Nils Zimmermann. The authors of the present article wish to express their appreciation to all who participated in the project. including numerous individuals in the Ministry of Forests, especially MoFs Inventory Branch. We would also like to thank anonymous reviewers for their helpful comments.
} 
87,500 direct jobs in 1989 (BC MoT 1991) compared to 84,700 jobs in the forest industry (Council of Forest Industries 1991).

In addition to the conflict between economic interests, the Valhalla proposal also reflects a shifting set of values and management theories surrounding wilderness, especially oldgrowth forests. Since 1912, when the provincial annual cut was 6.7 million cubic meters (Percy 1986), the cut has risen to a peak of 90.6 million cubic meters in 1987 (Council of Forest Industries 1991). In a single human lifespan, the extent of commercially operable old-growth forests (loosely defined as natural forests over 200 years old) has decreased to the point that the timber harvest falldown, symbolizing the depletion of virgin timber, is imminent (BC MoF 1984: D-6).

As these forests have disappeared, popular perceptions of their uses and values have changed. For example, $63 \%$ of respondents to a Canada-wide poll conducted in January 1989 stated that ecological concerns should take precedence in forestry land-use decisions, compared with $20 \%$ who cited economic values or job creation (McLaren 1989). In addition, the preservation value of the remaining forests increases with their increasing scarcity. In this regard, the conclusions of the United Nations World Commission on Environment and Development (the so-called Brundtland Commission) are relevant:

A consensus of professional opinion suggests that the total expanse of protected areas needs to be at least tripled [from $4 \%$ to $12 \%$ globally] if it is to constitute a representative sample of earth's ecosystems (1987: 165-166)

This shift in values has also entered the forestry profession, most notably, through the discussion of the need for "sustainable forestry". Such a concept differs greatly from the traditional notion of "sustained yield", which is largely a physical calculation for maximizing fibre production in the forest on a continuous basis. Sustainable forestry emphasizes the maintenance of long-term forest productivity, but within the context of ensuring ecological and genetic diversity (Dunster 1990). Thus it envisages adjusting economic and social demands on the forest to fit the needs of natural forest ecosystems (Perry et al. 1989). This approach contrasts sharply with the sustained yield policy of redesigning and simplifying forest ecosystems to maximize production in response to current and projected market demands (Maser 1988).

This shift in emphasis is controversial within the profession, considering its potential implications for harvesting techniques and cutting rates, and for the control and management of the forest. For example, while contemporary forestry is concerned primarily with the market values of forests, sustainable forestry points to the neglect of their inherent nonmarket values, especially in old-growth forests. These include ecological functions (such as maintenance of structural and functional bio-diversity of forests, protection of habitat, preservation of rare species, maintenance of local ecosystems and micro-climates, and so on), scientific functions such as maintenance of ecological benchmarks and genetic reserves, and cultural functions for society, especially native peoples. Concepts such as option value, existence value, and bequest value convey a range of often unpriced, long-term social and economic values affected by forest preservation or development. When given greater weight in decision-making, these functions and values help constitute the emerging concept of sustainable or "new" forestry.

\section{The Valhalla Proposal}

Sustainable forestry is largely concerned with land management, while the Valhalla proposal is concerned with land allocation. Nevertheless, the two processes are closely related, at least to the extent to which changes in land management (and timber processing) might lead to the more efficient utilization of a limited land base, thus helping to resolve allocation problems by reducing pressures on other lands. This is a significant point, helping to explain why wilderness advocates are so concerned with existing forestry practices in their search for a way to diversify the values and uses of the forest land base. This is also the challenge of integrated management.

When the Valhalla map was completed in 1988, approximately $5.3 \%$ of the provincial land base was designated as either provincial parks or recreation areas. To determine additional areas desired for protected status, the Valhalla Society utilized what might be called a "grassroots" approach - asking local wilderness groups throughout the province to delineate areas they wished to see set aside. The map is thus not definitive, as it does not include a range of other selection criteria which merit consideration, especially ecological criteria, such as the preservation of habitats for wildlife or those with special biogeographical significance. Although popular demand is a very important political criterion, our evaluation of the proposal can only be considered as a "case study". Implementation of any such largescale proposal would, of course, need to be undertaken by the government, and this would be done only after a much more comprehensive research and evaluation exercise.

To evaluate the actual physical implications of the Valhalla proposal, an extensive procedure was required to map the individual areas onto forest inventory maps, determine the inventory compartments involved, and calculate the timber volumes and sites affected. This procedure was complicated by a number of factors. First, some of the areas were located in Timber Supply Areas (i.e., lands comprising volume-based timber allocations where the Ministry of Forests holds management responsibility) while others were located in Tree Farm Licences (i.e., area-based tenures managed by individual companies). Information on TFLs was not available from the ministry, requiring that individual companies provide summary figures for the affected areas and volumes. Second, many of the proposed protected areas fell into portions of several forestry inventory compartments, necessitating proportional calculations of the volumes and sites affected for those inventory compartments. Finally, several of the wilderness areas identified by the Valhalla Society had been developed by the forest industry since compilation of the map. These were deleted from our calculations.

Area and volume data were aggregated by forest cover type (coniferous or deciduous) and site quality (low, poor, medium, good) down to the inventory compartment level. Data for both "gross" and "net" mature forest were used, the latter being that which is currently operable, and thus contributing to the long run timber supply. Economic criteria (such as development and harvesting costs) are not currently 
incorporated into the "netting-down", procedure by the Ministry of Forests, a fact which has the potential to exaggerate the operable timber volumes and areas used in this analysis by including areas which may be physically operable, but uneconomic to log.

The total area affected by the Valhalla proposal was calculated to be $6.5 \%$ of the province. If protected, this would increase the percentage of the province protected to $11.7 \%$, somewhat less than the $13.1 \%$ calculated by the Valhalla Society. This difference is partly attributable to the exclusions discussed above, but also to the greater precision of the NRM study's mapping methodology. More importantly, on a provincial level, $4.7 \%$ of the mature area and $4.7 \%$ of the net timber volume would be affected by these exclusions (see Table 1). This contrasts with a much higher impact on the gross mature area $(7.3 \%)$ and gross volume $(6.3 \%)$, indicating that proportionally more timber in proposal areas is netted out of the operable forest base than occurs on the province's forest land on average. That is, the Valhalla proposals contain more sites with low quality timber-growing land (such as high sub-alpine areas) than the provincial forest contains on average. It should be noted that the area affected is based on the actual withdrawals and may be higher if additional constraints are imposed on timber areas adjacent to the proposed parks.

\section{Effect on the Allowable Annual Cut}

With these reductions in the forest land base and timber supply come reductions in allowable cut. There is not, however, a direct correlation between reductions in the volume of timber available for cutting, and the rate of cut. This is because the level of allowable annual cut is set on the basis of many factors in addition to the volume of standing timber. One important factor is the growing potential of the sites in the operable land base. Because the Valhalla proposal includes a high proportion of sites of lower quality, its impact on the allowable annual cut is lower than its effect on the net land base.

The methodology used in this study for calculating changes in cut (Figure 1) includes several of the important factors used by the Ministry of Forests in determining the annual cut. It incorporates the 42 different timber type groups found in $\mathrm{BC}$, timber age and growth protential specific to sites within each affected TSA, and standards of timber decay, waste and breakage particular to different species, age classes, utilization diameters and sites within each TSA.

Section 7 of the Forest Act requires that the chief forester consider an area's sustainable rate of timber production or

Table 1. Summary of Valhalla proposal impacts on the net timber inventory

\begin{tabular}{|c|c|c|c|c|}
\hline Region & $\begin{array}{c}\text { Mature } \\
\text { net area } \\
\text { (ha) }\end{array}$ & $\begin{array}{l}\% \text { of } \\
\text { total } \\
\text { area }\end{array}$ & $\begin{array}{c}\text { Mature } \\
\text { net volume } \\
\left({ }^{\prime} 000 \mathrm{~m}^{3}\right)\end{array}$ & $\begin{array}{c}\% \text { of } \\
\text { total } \\
\text { volume }\end{array}$ \\
\hline Cariboo & 109,866 & 4.9 & 27,960 & 5.1 \\
\hline Kamloops & 47,965 & 2.6 & 13.587 & 2.9 \\
\hline Nelson & 49,249 & 5.3 & 17,214 & 5.8 \\
\hline Prince George & 155,217 & 3.1 & 35,801 & 2.6 \\
\hline Prince Rupert & 142,852 & 7.3 & 43,679 & 6.5 \\
\hline Vancouver & 145,310 & 7.6 & 87,908 & 6.3 \\
\hline Province & 650,459 & 4.7 & 226,148 & 4.7 \\
\hline
\end{tabular}

Note: Calculations based on January 1989 MoF data. long run sustainable yield (LRSY) when setting the allowable annual cut (AAC) for an area. In this study, it is assumed that a percent reduction in LRSY can be equated to a percent reduction in the current ACC. Because comparable data from TFLs were not available from the private corporate tenure holders (nor from the ministry which does not have such data), the percent reduction in cut was equated with the percent reduction in its total net productive area.

Using this methodology, the overall reduction in the provincial LRSY as a result of implementing the Valhalla proposal was calculated to be $3.52 \%$. This figure is substantially below the $10 \%$ reduction originally estimated by the Council of Forest Industries, as their forecast was imprecisely extrapolated from the total land area in the province which was presumed to be affected by the proposal, rather than the actual effect on the forest base.

This total impact is not evenly allocated between the coast and interior of the province, nor evenly spread across all regions of the province (Table 2 ). Impacts are especially variable between individual TFLs and TSAs. Half of the province's 66 TSAs and TFLs are not affected at all. For those TFAs and TFLs where proposed parks are contained, impacts on the cut range from $0 \%$ in the Revelstoke TSA up to $32 \%$ for the Queen Charlotte TSA. In 15 of the 28 TSAs affected, and 5 of the 6 TFLs affected, the estimated reduction is less than $5 \%$.

\section{Economic Impacts}

Much of the current debate surrounding wilderness designation of forest land focuses on the impact which reducing the AAC might have on jobs and government revenues. These are important considerations. Revenues collected from the forest industry help pay for social programs and infrastructure necessary to support regional development. The forest industry also provides important employment opportunities in regions with a limited economic base.

Fiscal and employment effects of implementing the Valhalla proposal were estimated using a model constructed from published statistical data on the BC forest industry and a provincial input-output model. Estimates of industry revenues and expenditures per cubic meter of harvest were multiplied by the anticipated reduction in the ACC to determine the effects of the Valhalla proposal on forest industry revenues and expenditures. Based on these projections, the fiscal impact of forest reallocation on provincial government revenues was estimated using effective tax rates applied to the appropriate revenue source. Employment impacts were derived from labour/production ratios using estimates of the average employment income for each industry grouping. These fiscal and employment impacts were disaggregated between coast and interior, and between logging, wood products, and various paper industries. Direct employment impacts were then multiplied by the appropriate employment multipliers, calculated using the BC input-output model maintained by the provincial Ministry of Finance and Corporate Affairs, to determine the possible effects of the Valhalla proposal on jobs in other sectors of the economy. ${ }^{3}$

Implementation of the Valhalla proposals could reduce government revenues (Table 3 ) by approximately $\$ 53$ million $(1988 \$)$ in the year in which the proposals are fully implemented. This reduction amounts to $0.5 \%$ of total provincial revenue. Forty-five percent of this decrease would 


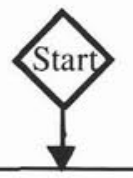

Compute weighted mean site index for each timber type, mature/immature type ID, and site class in proposed parks in each TSA. Weight site indexes in each inventory compartment by the total area of the compartment

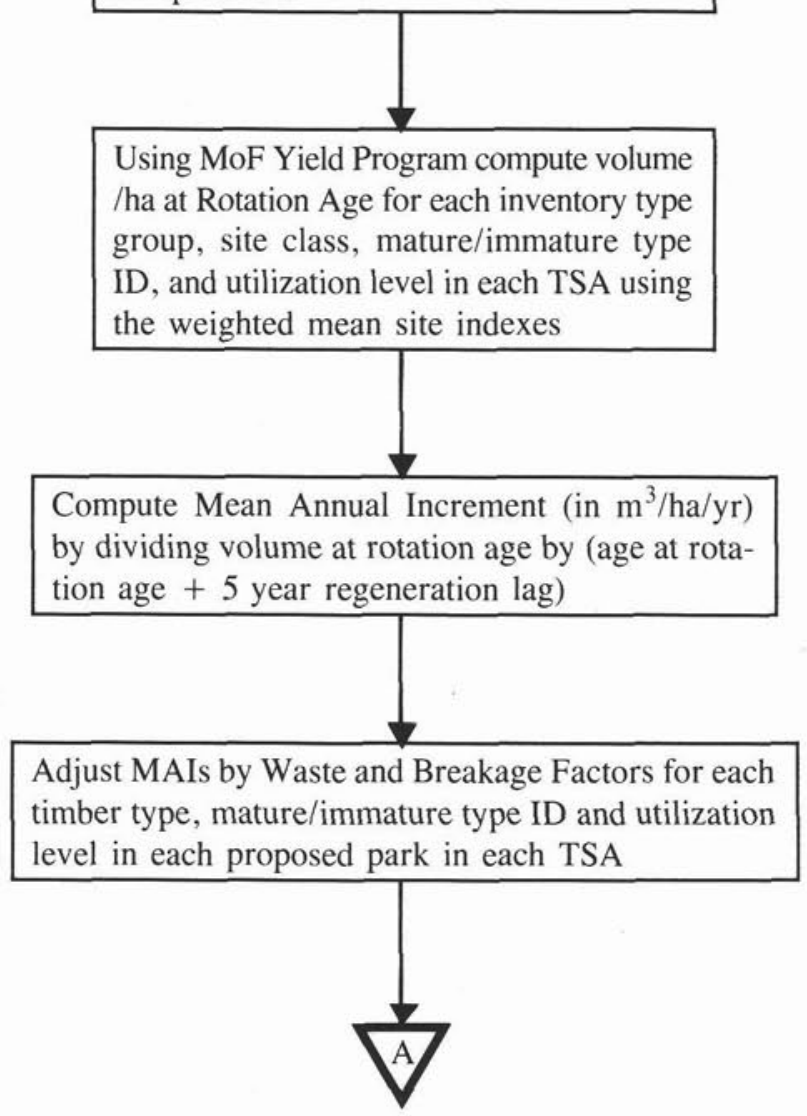

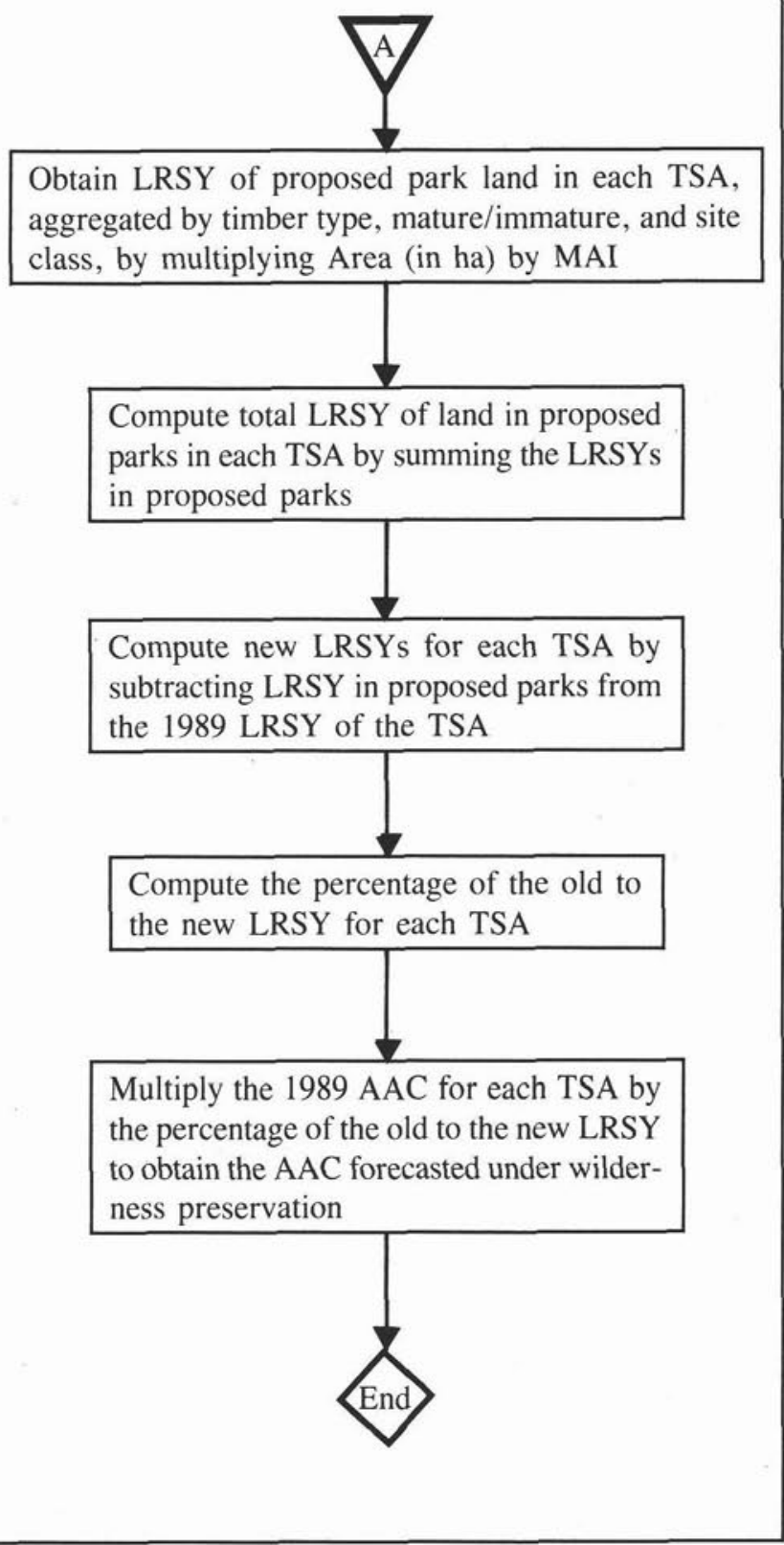

Figure 1. Procedure used to forecast AACs for Timber Supply Areas affected by the Valhalla proposal.

result from a loss of stumpage revenue. Most of the remaining reduction would be due to a decline in indirect revenues resulting from decreased forest industry expenditures.

\footnotetext{
${ }^{3}$ There is a range of employment multipliers used for the B.C. forest industry. The forest industry often uses a multiplier of 3 (Council of Forest Industries of B.C. 1988). Using an input-output model of the Canadian forest related economy in 1979, Jacques (1988) calculates a provincial multiplier for B.C. of 2.1. In its recent report, the B.C. Forest Resources Commission (1991) uses a multiplier of 2.05. White et al. (1989) use an economic base approach to estimate employment multipliers for forestry dependent communities in B.C. ranging between 2.20 and 2.36 . The study team utilized a multiplier of 1.9 which was obtained from the B.C. Ministry of Finance and Corporate Relations based on the Statistics Canada input-output model. This multiplier is comparable to the other multipliers estimated by inputoutput models which are the most reliable method for estimating multipliers.
}

Subsequent annual fiscal impacts will decline after the first year. This is because resources (capital and labour) displaced due to reduced forest industry activity will gradually be reemployed in other sectors of the economy. To the extent that these resources are employed elsewhere in $\mathrm{BC}$, new provincial tax revenue will partially offset tax losses caused by the reduction in timber harvesting. To the extent that the resources are employed outside $\mathrm{BC}$, the $\mathrm{BC}$ population will be smaller than before. The resulting reduction in provincial expenditures made possible by the reduction in $\mathrm{BC}$ residents may partially offset the revenue decline necessary to support services associated with industrial activity. Although these adjustments may be slow and incomplete, the revenue losses to the province will be at least partially offset over 
Table 2. Summary of Valhalla proposal impacts on the allowable annual cut by forest region

\begin{tabular}{|c|c|c|c|c|}
\hline $\begin{array}{l}\text { Region } \\
\text { effect }\end{array}$ & & $\begin{array}{c}\text { Existing AAC } \\
\left(\mathrm{m}^{3} / \mathrm{yr}\right)\end{array}$ & $\begin{array}{c}\text { Projected AAC } \\
\left(\mathrm{m}^{3} / \mathrm{yr}\right)\end{array}$ & $\begin{array}{c}\text { AAC } \\
(\%)\end{array}$ \\
\hline Cariboo & & $8,560,000$ & $8,112,007$ & 5.2 \\
\hline Kamloops & & $8,139,310$ & $7,966,026$ & 2.1 \\
\hline Nelson & & $6,098,700$ & $5,845,689$ & 4.1 \\
\hline Prince George & & $17,768,000$ & $17,430,697$ & 1.9 \\
\hline Prince Rupert & & $9,435,000$ & $9,040,954$ & 4.2 \\
\hline Vancouver & & $23,323,500$ & $22,351,014$ & 4.2 \\
\hline \multirow[t]{3}{*}{ Province } & Coast & $26,903,500$ & $25,875,655$ & 3.82 \\
\hline & Interior & $46,421,010$ & $44,870,802$ & 3.34 \\
\hline & Total & $73,324,510$ & $70,746,457$ & 3.52 \\
\hline
\end{tabular}

Note: Calculations based on January $1989 \mathrm{MoF}$ data.

time. However, even if no economic adjustment took place, the revenue impact represents $0.5 \%$ of provincial revenue. The fiscal impact of the wilderness proposal would therefore be quite small.

Approximately 2554 direct jobs in the forest industry could be affected by the implementation of the Valhalla proposal (Table 4). This represents a decline in B.C. forest employment of $3.1 \%$. In addition, 2357 related jobs would be affected through the multiplier effect, resulting in a total decline in employment of 4,911 jobs. This represents a decline in B.C. employment of $0.3 \%$. Given normal turnover in the forest industry and the ability to phase in the reductions, the overall impact of these reductions would not cause significant dislocation in the industry or the B.C. economy. Nevertheless, serious social dislocations could occur in some areas where the reductions in cut are highest, especially in communities particularly dependent on the forest industry. Consequently, readjustment policies to offset dislocation should be provided.

These results are based on the assumption that the Valhalla proposals are fully and immediately implemented, with a corresponding reduction in the AAC. If the government gradually reduced the AAC, or did so in combination with offsetting policies and programs, social dislocation could be reduced.
The normal qualifications in economic impact analysis should be kept in mind when interpreting these results. First, estimates of the AAC impacts are based on B.C. Ministry of Forest data which are estimated to have a margin of error of plus or minus $10 \%$. Second, the economic and fiscal impacts assume a linear relationship between $\mathrm{AAC}$ and total forest sector output. Due to economies of scale in the industry, a percentage reduction in the AAC could result in a higher percentage reduction in total industry output. A small reduction in fibre, for example, may result in the closure of an entire sawmill. Finally, the estimates including the multiplier impacts, are based on a static analysis of the economy. Actual impacts may vary with changes in production functions and tax rates. For these reasons, the actual impacts could be lower or higher than those forecast.

\section{Offsetting Policies I: Enhanced Timber Management}

Recent studies indicate the potential for generating additional forest production through better timber management, wood processing, and marketing. Although these policies should be evaluated independent of any wilderness strategy, they do illustrate the potential for offsetting reductions in forestry activity due to wilderness designations. Given that any reduction in forestry employment will be controversial and disruptive, the ability of offsetting policies to maintain or enhance forestry employment could significantly increase the workability of wilderness policies, and is therefore integral to the analysis.

One timber management strategy is to enhance the timber supply. Industrial timber management comprises several interrelated categories including: forest inventories, silviculture, soil conservation and maintenance of productivity, protection from fire, insects, and disease, and timber extraction. In different jurisdictions, different combinations of policies might be available to achieve the objective of enhanced timber management. In this study, we focused on only one strategy, improvements in silviculture.

Table 3. Impact of the Valhalla proposal on provincial revenue in the first year following full implementation ${ }^{1}(1988 \$)$

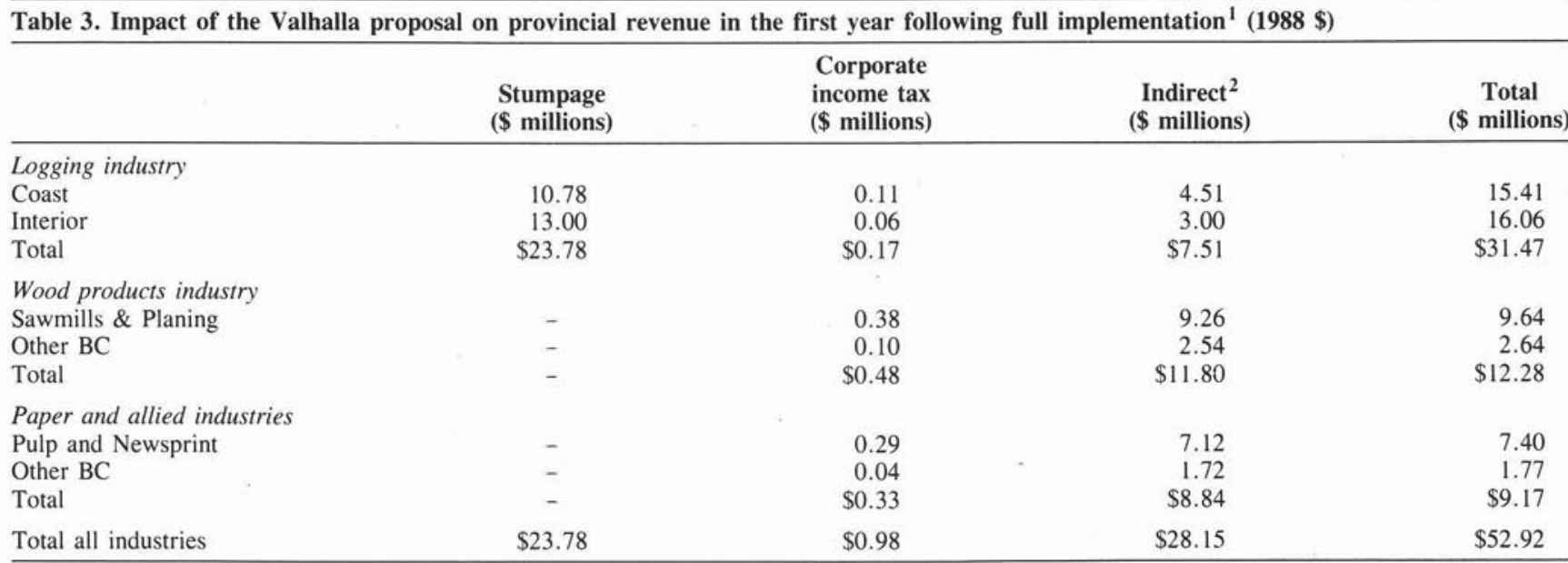

${ }^{1}$ Calculated based on a $3.52 \%$ reduction ( 2.58 million cubic metres) in the provincial allowable annual cut. Results for the coast and interior based on regional decreases in the AAC of $3.82 \%$ ( 1.03 million cubic metres) and $3.34 \%$ ( 1.55 million cubic metres), respectively. Fiscal impacts based on the assumption that full implementation of the Valhalla proposal would result in an immediate reduction in the AAC.

${ }^{2}$ All indirect taxes have been "backed-out" of expenditures in order to avoid overestimation of taxes paid (Price Waterhouse 1987. The contribution of the British Columbia forest industry to the federal municipal governments. Vancouver, BC: COFI). Indirect taxes include personal income taxes, provincial sales tax, gasoline and fuels tax. 
Table 4. Impact of the Valhalla proposal on provincial employment in the first year following full implementation 1

\begin{tabular}{|c|c|c|c|}
\hline & Direct & $\begin{array}{c}\text { Indirect } \\
\text { and induced }^{2}\end{array}$ & Total \\
\hline \multicolumn{4}{|l|}{ Logging industry } \\
\hline Coast & 438 & 666 & 1,104 \\
\hline Interior & 259 & 394 & 653 \\
\hline Total & 697 & 1,060 & 1,757 \\
\hline \multicolumn{4}{|c|}{ Wood products industry } \\
\hline Coast & 375 & 191 & 566 \\
\hline Interior & 504 & 257 & 761 \\
\hline Other BC & 364 & 186 & 550 \\
\hline Total & 1,243 & 634 & 1,877 \\
\hline \multicolumn{4}{|c|}{ Paper and allied industries } \\
\hline Coast & 365 & 394 & 760 \\
\hline Interior & 115 & 124 & 239 \\
\hline Other BC & 134 & 145 & 279 \\
\hline Total & 614 & 663 & 1,277 \\
\hline Total all industries & 2,554 & 2,357 & 4,911 \\
\hline
\end{tabular}

${ }^{1}$ Calculated based on a $3.52 \%$ reduction ( 2.58 million cubic metres) in the provincial allowable annual cut. Results for the coast and interior based on regional decreases in the AAC of $3.82 \%$ (1.03 million cubic metres) and $3.34 \%$ ( 1.55 million cubic metres), respectively. Employment impacts based on the assumption that full implementation of the Valhalla proposal would result in an immediate reduction in the ACC.

${ }^{2}$ Indirect employment is work in industries supplying goods and services to the forest industry. Induced employment is employment in industries providing goods and services to forest industry workers and their families.

Silviculture activities may be used to meet various timber management objectives, including increasing the available volume at harvest, shortening the time between harvests, or increasing wood value over that expected from unmanaged forests. Activities include planting, use of special genetic stock, manipulation of stocking density, rehabilitation of unstocked but potentially productive land, removal of competitive plants, fertilization, and stand tending. Each of these areas warrants attention as part of any comprehensive strategy that seeks to balance wilderness protection with policies aimed to maintain, or improve, the forest industry.

Only a single aspect of this one strategy was examined for its potential to offset the impact of wilderness designations - rehabilitation of land which is not satisfactorily restocked (so called NSR land) after logging, fire, or infestation. On "backlog" NSR land, the allowable period for restocking after disturbance (from 3 to 5 years in $\mathrm{BC}$ ) has expired (Pearse et al. 1986a).

In British Columbia, recent figures indicate that over 845,000 hectares of land qualify as net backlog NSR land with 553,145 ha of this amount on good and medium quality sites which are accessible and economically viable to treat (B.C. Min. For. 1988). Good and medium quality NSR sites are referred to as "priority backlog". Costs associated with treating such lands vary accordingly to whether the lands are selected on a cost-effectiveness basis. According to Pearse et al. (1986b), an expenditure of $\$ 142$ million on the most cost effective sites could increase the provincial forest growth rate (the mean annual increment) by 1.2 million cubic meters, an investment of $\$ 118$ per cubic meter of annual increment.

Net mature forest areas of good and medium quality sites within the Valhalla proposal is compared with net priority backlog NSR sites by forest region (Figure 2). In all regions except Vancouver, the priority backlog NSR sites exceed comparable sites in the Valhalla proposals. Overall, this excess totals over 300,000 hectares. Thus, restocking of NSR land could bring into production an area of high quality timber-growing land greater than the area of similar land potentially removed by the entire Valhalla proposal. An investment of some $\$ 500$ million could increase the annual growth rate by 2.6 million cubic meters, amounting to $3.6 \%$ of present AAC of 72.5 million cubic meters. ${ }^{4}$ The AAC could be increased immediately in anticipation of this increase

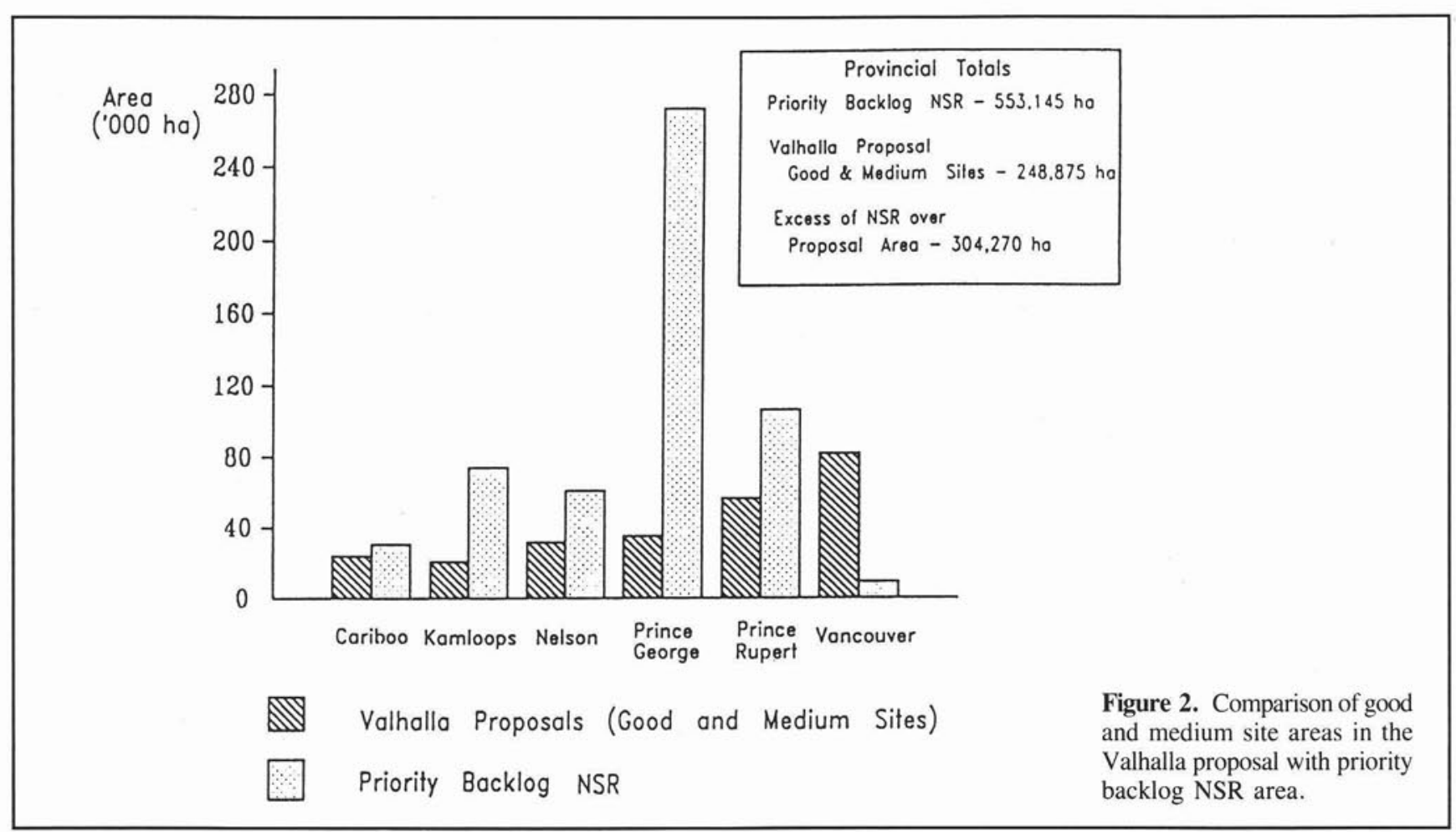


in future timber growth, the so-called Allowable Cut Effect (ACE) (Schweitzer et al. 1972; Cdn. For. Serv. 1985). However, due to uncertainties about long-term forest plantation growth and effects of silviculture, current silvicultural efforts should be relied on only for long-term expansion of timber harvest levels.

Just this one component of one area of timber management offers the potential to offset the annual cut reduction resulting from allocation of land to wilderness protection. In addition, these expenditures would lead to job creation, although not in the logging sector, in regions affected by wilderness designations.

\section{Offsetting Policies II: Enhanced Wood Processing}

In addition to opportunities available in timber management, opportunities exist for effectively expanding forestry production by utilizing the wood resource in $\mathrm{BC}$ more efficiently, both physically and economically.

Numerous studies reveal the potential to expedite an ongoing shift in direction to enhanced value-added manufacturing in the solid wood and paper products sectors. For example, Petro (1981) stresses the need for sorting to ensure that logs are sent to their best use, while McWilliams (1988) and Schuler (1989) emphasize that matching resources and mill use processes to market preferences increases profitability and competitiveness. Deloitte, Haskins and Sells (1988) discuss more generally the opportunities for diversifying solid wood product manufacturing and increasing product recovery efficiency during milling. Finally, while there are barriers to expansion of specialty paper manufacture in BC (BC Ministry of Forests 1984: J7-J16), there are also opportunities for diversification from the current emphasis on pulp and newsprint commodities (Anonymous 1988, Anonymous 1989a and 1989b, MacMillan Bloedel 1988).

An enhanced industry and government focus on adding value would not increase the volume of timber standing in the forest, but could maintain or increase the economic benefits (employment and revenues generated from timber harvests). If the timber harvest is viewed as a creator of economic services rather than as a purely physical product, maintaining a particular harvest level becomes less important than achieving desired employment and revenue objectives. Manufacture of high value wood products, by providing equivalent economic benefits from a lower volume of timber than commodity production, indirectly offsets some impacts of removing forest areas from timber production.

For example, wood from thinnings, still an underutilized wood source in British Columbia, has been estimated to be capable of supplying 10-25\% of the annual harvest (Assoc. of B.C. Prof. For. 1981). About one-quarter of the Swedish timber harvest currently comes from thinnings (The Swedish Institute 1988). In addition, utilization of the deciduous resource, primarily aspen, could be significantly increased to complement the traditional reliance on coniferous species (Thorp 1986). This is already occurring in some areas. As well, an industry which manufactures a diverse assortment of end products and uses technology designed for lower

\footnotetext{
${ }^{4}$ This figure is based on growth rates adapted from: Nawitka Resource Consultants. 1987. Impact of intensive forestry practices on net stand values in British Columbia. FRDA Report 14. BC Ministry of Forests. Victoria, BC.
}

quality logs could make profitable use of currently uneconomical logs which are left on site (Woodbridge Reed and Assoc. 1988).

Log recovery could be enhanced as well. Currently, lumber recovery factors (LRFs) range from 42 to $49 \%$, depending on species. Technologies such as thin kerf sawing (Kirback 1989) and computer optimization (Harpole and Hallock 1977) can improve lumber recovery efficiency. These technologies, as well as additional remanufacturing could increase fibre recovery to $50-88 \%$ (Deloitte, Haskins and Sells 1988). In various scenarios investigated by Deloitte, Haskins and Sells, it was concluded that mills could increase LRFs by $4-11 \%$ without capital investment. A $5 \%$ fibre recovery improvement on current sawmill output is capable of effectively increasing timber supply by 3.7 million cubic meters annually, or $30 \%$ more than the AAC reduction potentially resulting from the Valhalla proposals.

A greater emphasis on value-added manufacturing would also increase employment, as this sector is more labour intensive than primary sawmilling because of the need to manufacture to diverse specifications. BC currently employs relatively few people for its harvest level compared to some other jurisdictions with similar forest industries (Table 5). This presents great opportunities when one considers the high quality of the old-growth timber being processed in relatively unsophisticated form in BC.

At the provincial level, it has been estimated that an increase in industry revenue of $\$ 1.8$ billion may be possible by marginally increasing the volume of specialty products produced by the remanufacturing industry, along with improving grade and fibre recovery in primary sawmills (Deloitte, Haskins and Sells 1988). The necessary remanufacturing facilities to achieve this revenue would cost approximately $\$ 600$ million and would employ 3900 people.

Again, although these policies should be evaluated independent of land use allocations, they do illustrate the potential for offsetting employment losses associated with wilderness withdrawals. This is an important factor affecting the feasibility of wilderness policies.

\section{Conclusion: Integrated Planning for Sustainable Forestry}

This study has developed an economic model for assessing the impacts of wilderness policies on the British Columbia

Table 5. Comparison of 1986 employment per volume harvested: British Columbia, northwestern U.S., and Sweden

\begin{tabular}{|c|c|c|c|}
\hline & $\begin{array}{l}\text { Forest industry } \\
\text { employment }\end{array}$ & $\begin{array}{c}\text { Harvest } \\
\left({ }^{\prime} 000 \mathrm{~m}^{3}\right)\end{array}$ & $\begin{array}{l}\text { Jobs per } \\
, 000 \mathrm{~m}^{3}\end{array}$ \\
\hline British Columbia & 82,500 & 77,503 & 1.06 \\
\hline Idaho & 15,000 & 7,468 & 2.01 \\
\hline Montana & 8,100 & 5,618 & 1.44 \\
\hline Oregon & 72,900 & 37,980 & 1.92 \\
\hline Washington & 53,100 & 27,641 & 1.92 \\
\hline Alaska & 2,700 & 2,562 & 1.05 \\
\hline Sweden & 141,000 & 64,000 & 2.20 \\
\hline
\end{tabular}

Sources: COFI. 1988. British Columbia Forest Industry Fact Book. Canadian Forestry Service. 1988. Selected Forestry Statistics 1987. Information Report E-X-40.

USDA Forest Service. 1988. Production, prices, employment, and trade in Northwest forest industries. Second quarter. Portland, Oregon: USDA Forest Services. Resource Bulletin PNW-RB-61.

Swedish Forest Industry Public Communications. 1988. Sweden's Forest Industry. Stockholm. 
forest industry. The results indicate that, overall, the impacts are relatively small, involving a $3.5 \%$ reduction in the provincial AAC, with regional impacts ranging from $1.9 \%$ in Prince George, to $5.2 \%$ in the Cariboo. In addition, the study indicates that there are ways in which these impacts can be offset. The ability to offset employment losses is a significant factor influencing the feasibility of wilderness policies. The study does not, however, consider economic benefits of wilderness protection, but notes wide potential benefits accruing to other sectors, most notably tourism, and the importance of nonquantifiable ecological, scientific and cultural benefits associated with wilderness, and especially old growth forest preservation.

Perhaps more important than the specific findings related to the Valhalla proposal are the more general findings regarding the development of quantitative models for assessing the economic impacts of land use options at the provincial level. This paper indicates that the development of these techniques is feasible and useful in informing decision makers. To this end, it would be useful to extend the model developed in this paper by integrating the province's growth and yield models with a geographical information system and the province's input-output model. The integration of these models will allow for quick and flexible assessments of alternative land use allocations. Also, the model could be extended to include cost-benefit analysis by incorporating spatially disaggregated cost and revenue data. Although disputes may exist on data inputs and overall objectives and values, the development of such a framework for assessing alternative land use strategies is essential to resolving forestry conflicts.

\section{References}

Anonymous. 1988. Big push coming for specialty newsprint. Pulp and Paper Journal. January.

Anonymous. 1989a. Add more value to paper products study of Canadian industry says. Pulp and Paper Journal. March.

Anonymous. 1989b. Forest products industry must change its ways, spend more to realize opportunities. Pulp and Paper Journal. June. Association of B.C. Professional Foresters. 1981. Forest Memo. 13 (July). Vancouver, B.C.

B.C. Forest Resources Commission. 1991. The future of our forests. Victoria, B.C.

B.C. Ministry of Finance and Corporate Relations. 1989. Estimates of revenue and expenditures. Victoria, B.C.

B.C. Ministry of Forests. 1984. Forest and range resource analysis. Victoria, B.C.

B.C. Ministry of Forests. 1988. 1988 Summary of backlog not satisfactorily restocked forest land. Victoria, B.C.

B.C. Ministry of Tourism. 1991. 1990 Highlights. Victoria, B.C. mimeo.

Canadian Forestry Service. 1985. Benefit cost analysis for forestry investments. Information Report BC-X-275 by G.A. Fraser. Victoria, B.C.

Council of Forest Industries of British Columbia. 1988. British Columbia forest industry fact book. Vancouver, B.C.

Council of Forest Industries of British Columbia. 1991. British Columbia forest industry statistical tables. Vancouver, B.C.

Deloitte, Haskins and Sells. 1988. A value strategy for BC solid wood products. Canada, Dept. of Reg. Ind. Exp. and B.C. Min. of Ec. Dev. Vancouver, B.C.

Dunster, J.A. 1990. Forest conservation strategies in Canada. Alternatives 16(4)/17(1): 44-51.

Hall, N. 1990. Temagami: the battle to protect "Deep Water" country. Borealis 1(4): 14-21.
Harpole, G.B., Hallock, H. 1977. Investment opportunity: best opening face sawing. USDA For. Serv., For. Prod. Lab. Res. paper FPL 291. Madison, WI.

Jacques, R. 1988. Impact of forest activity on the economy of Canada and its provinces: An input-output approach, Information Report E-X-39. Canadian Forest Service, Ottawa, Ont.

Kirkback, E. 1989. Thin-kerf sawing: how to make it work. For. Ind. 116(5): T6-T10.

MacMillan Bloedel. 1988. Adding value: a special supplement to the MB Journal. August. Vancouver, B.C.

M'Gonigle, M. 1989. The unnecessary conflict: resolving the forestry/wilderness conflict. For. Chron. 65: 351-358.

McLaren, C. 1989. "Canadians want logging changed, poll finds". Globe and Mail. May 19. A3

McWilliams, J. 1988. S\&R taps lucrative custom cutting market. Cdn. For. Ind. Jan.: 18-22.

Maser, C. 1988. The redesigned forest. R\&E Miles, San Pedro, California.

NRM. 1990. Wilderness and forestry: Assessing the cost of comprehensive wilderness protection in British Columbia. SFU-NRM Report No. 6. Natural Resources Management Program, Simon Fraser University, Burnaby, B.C.

Nikiforuk, A. and E. Struzik. 1989. The great forest sell-off. Report on Business Magazine 6(5): 56-68.

Pearse, P.H., A.J. Lang and K.L. Todd. 1986a. The backlog of unstocked forest land in British Columbia and the impact of reforestation programs. For. Chron. 62: 514-21.

Percy, M.B. 1986. Forest management and economic growth in British Columbia. Study prepared for the Econ. Coun. Cda. Supply and Services Cda., Ottawa, Ont.

Perry, D.A., R. Meurisse, B. Thomas, R. Miller, J. Boyle, J. Means, C.R. Perry, and R.F. Powers. 1989. Maintaining the long-term productivity of Pacific Northwest forest ecosystems. Timber Press, Portland, Oregon.

Petro, F. 1981. Log quality and its effect of sawmill efficiency. In: Proceedings of the small log workshops. pp. 11-16. Special Public. No. SP506E. Forintek Canada Corp. Eastern Lab., Ottawa, Ont.

Reed, F.L.C. 1984-5. Reshaping forest policy in British Columbia. Jnl. Bus. Admin. 15: 111-137.

Sasges, M. 1988. "Wish list on parks to kill 8.500 jobs: forest council. Vancouver Sun. 7 December. D11.

Schuler, A. 1989. Selecting a competitive strategy for the future. Cdn. For. Ind. Feb: 66-70.

Schweitzer, D.L., R.W. Sassaman and C.H. Schallau. 1972. Allowable cut effect: some physical and economic implications. Jnl. For. 70(\&): 415-418.

The Swedish Institute. 1988. Fact sheets on Sweden: Forestry and Forest Industry. Stockholm, Sweden.

Thorp, W.K. 1986. Industrial perspective: the deciduous resource in the Peace River Land District. In: Forestry or agriculture: A case for diversification. FRDA Rep. No. 042. pp. 13-15. For. Res. Dev. Agmt., B.C. Ministry of Forests, Victoria, B.C.

United Nations World Commission on Environment and Development. 1987. Our common future. Oxford University Press, New York.

Valhalla Society. 1988. B.C.'s endangered wilderness: A comprehensive proposal for protection. New Denver, B.C.

White, W.A., K.M. Duke and K. Fong. 1989. The influence of forest sector dependence on the socioeconomic characteristics of rural British Columbia. Information Report BC-X-314. Forestry Canada, Pacific and Yukon Region, Victoria, B.C.

Woodbridge, Reed and Assoc. 1988. The status and direction of the lumber remanufacturing sector in British Columbia. FRDA Report 045. For. Res. Dev. Agmt. B.C. Ministry of Forests, Victoria, B.C. 